\title{
Economic and Political Reform in Post-Mao China
}

\author{
KJELD ERIK BRØDSGAARD
}

East Asia Institute, University of Copenhagen

Since the death of Mao Zedong in 1976 and Deng Xiaoping's second return from disgrace in 1977, China has been in the middle of a great transformation and modernization process which as its overarching goal aims to turn China into an industrialized, developed country by the middle of the next century. Since December 1978, a reform of the rigid and overly centralized political and economic systems has been an integral part of the modernization program.

The economic reforms involve adopting measures to (1) decentralize decision-making power to the production units, whether enterprises in the urban state sector or households in the rural sector, (2) enhance material incentives to stimulate economic efficiency and productivity, (3) substitute administrative planning methods by economic levers (jingji ganggan), e.g. credit control, interest rates, taxes, and prices, (4) and allow the market mechanism to play a role in resource allocation and distribution.

Of the Chinese post-Mao reforms those in the economic realm have attracted the greatest attention in China as well as abroad. However, in the latter part of 1980, the issue of political reform also became the subject of a significant debate among the Chinese leaders and in the Chinese media. The debate was taken off the agenda in 1981 and effectively suppressed during the campaign against spiritual pollution (jingshen wuran) in late 1983.

Recently, the need for political reforms has reappeared as an important theme in the Chinese political discourse and the concept of reform of the political system (zhengzhi tizhi gaige) is now as widely discussed as reform of the economic system (jingji tizhi gaige).

The present paper will focus on the evolution of economic and political reform in the post-Mao era. It will be argued that although economic reforms were being introduced and implemented from 1979 onwards, the road toward basic systemic reform was blocked by the absence of a simultaneous change of the political system. That the issue of political reform has resurfaced in China 
now, ten years after Mao, may signify that economic and political reformers have joined forces and that major systemic changes are likely.

A postscript has been added to the main body of the article in order to analyze the significance of the fall of General Secretary Hu Yaobang in January this year. It is based on a collection of CCP Central Documents (zhongfa) that have a restricted circulation in China and, in principle, are unavailable to Western analysts of Chinese politics.

\section{Economic Reform}

The present Chinese economic reform process started in October 1978, when Sichuan Province undertook an experiment, granting expanded decisionmaking power to a selected group of enterprises. During 1979 and 1980, the scope of the reforms were considerably extended, and by the end of 1980 some 6600 enterprises throughout the country were involved. ${ }^{1}$ These enterprises accounted for 60 percent of the value of industrial output and 70 percent of total state owned enterprise profit. It was decided that in 1981 the new economic management system would encompass all state enterprises in the country. ${ }^{2}$

Soon, however, the introduction of economic reforms ran into major difficulties. The expanded decision-making powers for enterprises had caused extra-budgetary funds to increase sharply in 1979 and $1980 .{ }^{3}$ As a consequence, the government lost control over capital construction, and investment increased rapidly, creating serious imbalances in the economy. Budget deficits and inflation further aggravated the situation, and in late 1980, the leadership decided to call a halt to the implementation of further reform measures.

Recentralization was stressed, and centralized control and planning were to be strictly enforced not only in capital construction, but also in the allocation of raw materials and primary products, in rates of profit retention, in price policies, etc. ${ }^{4}$ It was clear that the aim of simultaneously readjusting and reforming the economy had run into major difficulties, and it was decided that for the time being readjustment and consolidation were to have priority over reform. ${ }^{5}$

\section{The Economic Responsibility System}

In the 1981-1982 period, the reform process was only slowly unfolding, and in the urban sector emphasis was placed on the introduction of the so-called 
economic responsibility system (jingji zeren $z h i) .6$ This system that was inspired by developments in the agricultural sector defined the responsibilities and tasks of every workshop, shift, team, and individual in a given enterprise. It also specified the exact amount of bonus to be received for the overfulfilment of each job assignment. At Capital Iron and Steel Company, for example, there were more than 230.000 targets for the different kinds of work at the factory. The system was regarded as a sophisticated kind of "scientific management" and was much propagated in Chinese publications in 1982.

The reform discussion surfaced again in mid-1982. Earlier reform measures had centered primarily on individual enterprises, but now the reform process also began to address issues concerning the very core of the Chinese planning system: namely, the relationship between plan and market in economic planning.

\section{Plan Versus Market}

In January 1982, Chen Yun convened a meeting with leading members of the State Planning Commission to discuss the relationship between plan and market in the Chinese economic system. In the wake of the meeting there unfolded among Chinese economists an interesting debate on the relationship between planned economy and regulation by the market mechanism. ${ }^{7}$

All participants in the debate agreed on a strategy that combined central planning with the market mechanism. But they differed in their views on what this meant in practice. The advocates of comprehensive planning argued that the slogan of "taking the planned economy as the dominant factor and the market as the supplement" (yi jihua jingii wei zhu, yi shichang tiaojie wei fu) should be taken literally. The plan was superior to the market and a prerequisite for socialist development. This group also denied that the economic problems of the past were caused by central planning: "The tortuous path along which our economy has developed has not been caused by planned economy, but because we have violated planned economy. ${ }^{\prime 8}$ Finally, they claimed that it was wrong to hold that planning meant governing the economy by way of orders from above and that the plan therefore could not respond flexibly to market demands. In sum, this group wished to retain a planned economy and the changes that they thought were needed were aimed at perfecting the planning system rather than abolishing it.

The adherents of reducing the scope of central planning argued that the present system was restraining the possibilities of exploiting the full potential of 
the enterprises. They wanted to further expand the role of the market forces by instituting a system of guidance planning and market regulation. Said Xue Muqiao: "Mastering true methods of applying economic levers, gradually reducing mandatory plans and replacing them with guidance plans for reference is an important part of the future reforms of our planning system. ${ }^{\prime 9}$ In short, according to this group, the crucial role given to the plan constituted an obstacle to economic development, and it was therefore necessary to establish an economic system that also reflected regulation of supply and demand by the market.

Hu Yaobang's report to the 12th Party Congress, on September 1, 1982, seemed to indicate that a compromise had been reached on the issue of plan versus market. Hu outlined an economic planning system which contained three elements: mandatory planning (zhilingxing jihua), guidance planning (zhidaoxing jihua), and market regulation (shichang tiaojie). ${ }^{10}$ Mandatory planning should be enforced in regard to the production and distribution of capital goods and consumer goods in the state sector which were vital to the national economy. Guidance planning, i.e. planning which is mainly implemented by economic levers rather than by administrative means, should be used in regard to the rest of the economy, except for a small number of commodities "which are low in output value, great in variety, and produced and supplied only seasonally and locally." As it was neither necessary nor possible for the state to control these by planning, they should be produced and distributed in accordance with the law of supply and demand.

Hu claimed that some reform measures had not been well coordinated with each other. This had caused problems for the functioning of the state's unified plannning system, and he warned:

Hereafter, while continuing to give play to the role of market regulation, we must on no account neglect or relax unified leadership through state planning. ${ }^{11}$

A few days later, the People's Daily published an article by Liu Guoguang, the new head of the Economic Research Institute of the Chinese Academy of Social Sciences. ${ }^{12}$ The article differed from $\mathrm{Hu}$ Yaobang's speech by explicitly questioning the merit of central planning. Thus, Liu Guoguang criticized a "certain viewpoint" according to which "mandatory targets are the principal symbol of the planned economy; the greater the number of such targets, the stronger planning will be; and following the improvement of the level of plan management, the scope covered by mandatory plans will become larger and larger."13 
According to Liu Guoguang, such a viewpoint is questionable because it does not take into account that central planning has advantages as well as disadvantages:

The experience of all countries that have adopted a mandatory plan system shows that such a plan management form is relatively weak in solving those traditional shortcomings that are intrinsic to a centralized planning system, such as the gap between production and demand, waste of resources, poor quality and lack of varieties of products, and poor microeconomic results. ${ }^{14}$

Liu also claimed that the experience of countries practicing a centralized planning system for a long time shows that "the consequences of microeconomic returns being lowered had gradually outweighed its superiority in terms of macroeconomic returns." This had, in his opinion, led to a situation where the slowing down of the growth rate of the whole economy "can hardly be reversed, and the imbalance of the economic structure can hardly be redressed." ${ }^{\prime \prime}$

Liu's conclusion was that the expansion of the scope of mandatory planning cannot be the direction structural reform should take in the case of the Chinese economy. On the contrary, it was necessary gradually to reduce the scope of the plans which are mandatory in nature and expand the scope of plans which are indicative in nature, i.e. so-called guidance plans.

Two weeks after Liu's article had appeared, the People's Daily published an authoritative Commentator's article on the issue of plan versus market in Chinese economics. ${ }^{16}$ The article stressed the importance of mandatory planning. It argued that if planning is abandoned as the guiding principle "the unified state-run economy will deviate from serving the people's interests and from the socialist orientation, and the entire social system will develop under the spontaneous forces of the market. ${ }^{\prime 17}$

In a clear rebuttal of Liu's criticism of the mandatory planning system, the Commentator's article stated that it is "groundless to assert" that production under mandatory planning always will result in "a gap between production and demand, waste of resources, poor quality, and less variety of products, and low microenomic efficiency ${ }^{\prime \prime} .^{18}$

The Commentator's article amounted to an official criticism of Liu Guoguang's position on reform of the Chinese economic planning system. However, apparently, Liu survived this "incident" without having had to make a self-criticism. In fact, during an interview at the Chinese Academy of Social Sciences in December 1982, Liu reiterated his position. ${ }^{19}$ 
It is remarkable that Liu's article appeared only 6 days after Hu Yaobang's report and while the Party Congress was still in session. Under these circumstances, the article could probably not have been published without clearance from the top echelon of the power hierarchy. This leads us to two possible assumptions. One is that "someone" wished to signal to Hu Yaobang and the Party that Hu's report did not meet with unanimous approval and support, and that the opponents of Hu were strong enough to have their views published at this particular time. The second, and more likely assumption, is that Liu Guoguang was in agreement with $\mathrm{Hu}$ Yaobang, and that he only wrote what Hu would have said in his report, had he not had to compromise between contending parties in his position as Party leader. By using Liu as a mouthpiece, Hu could get his message across without running the risk of being the target of possible reprisals from the conservative wing of the Party. Liu, on the other hand, could count on the support of Hu Yaobang, and therefore he had reason to believe that he did not run too much of a risk by publishing his reform-oriented views.

\section{Economic Retrenchment}

By late 1981, it seemed that the readjustment policy adopted in December 1978 and further strengthened in December 1980 was succeeding in its twin goals of (1) slowing down the growth rate of heavy industry in favour of agriculture and light industry and (2) reducing the accumulation rate. However, statistics published in 1983 revealed that the old pattern of heavy industryoriented growth was re-emerging. For example, state capital construction in 1982 had ballooned to a record high of 55,5 billion Yun and the output of heavy industry had increased $9.9 \%$ which was $8.9 \%$ higher than the planned figure of $1 \%$. These trends continued in the first half of 1983 . Heavy industry rose $12.2 \%$ over the 1982 period, far outstripping the planned annual growth rate of $3.9 \%$. Furthermore, the volume of capital construction also increased rapidly during the first months of 1983 , bringing the amount for the first half of 1983 up to a level $14.7 \%$ higher than the previous year. ${ }^{20}$

In July, a CCP Working Conference convened to arrest this development, and an emergency circular from the State Council called for an immediate economic retrenchment. ${ }^{21}$ However, this time the reform process did not come to a complete standstill. In the urban sector, there were further attempts to reform the financial system and the wage and labor systems, and in the countryside the separation of government administration from the rural people's communes was carried out. ${ }^{22}$ In mid-1983, a major tax reform was intro- 
duced, according to which the profit retention schemes would be substituted by a new enterprise taxation system. The new system was to be introduced in stages. The first stage involved the imposition of income tax on all state enterprises coupled with a sharing of post-tax profits between the individual enterprise and the central budget. The next stage would try to reduce disparities in after-tax profits by introducing a readjustment tax that would ofset variations in profitability due to factors external to the enterprise, in particular the irrational price system. ${ }^{23}$

Nevertheless, in 1984 Xue Muqiao complained that the reforms had only resulted in partial and minor alterations of the system and that the enthusiasm of enterprises and workers had been stifled by attempts to recentralize. Said Xue Muqiao:

It is necessary to conduct a major reform in the planned management system, to give full play to the role of key cities, to delegate more decisionmaking power to the enterprises and workers, and to separate government administration from enterprise management in a step-by-step manner. In recent years we have conducted some reform experiments in the urban econmy at selected points and we have delegated some financial decision-making power to lower levels, but the enterprises cannot yet manage to assume sole responsibility for their own profit and losses after paying taxes. Moreover, there have been no changes by and large in the personnel and labor management system and only minor changes (some changes were made by the enterprises in making breakthroughs instead of following the old principle, some power was recalled shortly after being delegated), in the decision- making power over materials (including supply, production and marketing), thus the enthusiasm of enterprises and workers has not been fully aroused. ${ }^{24}$

In this passage, Xue Muqiao, dissatisfied with a reform process focussing on the introduction of partial and experimental reform, clearly calls for more comprehensive and lasting reform efforts.

\section{The Second Reform Phase}

A new reform strategy was, in fact, already on its way. The new strategy was embodied in a comprehensive reform package that had been prepared by the Committee on the Reform of the Economy (jingji tizhi gaige weiyuanhui) and was adopted at the Third Plenary Session of the 12th Party Congress in October 1984. ${ }^{25}$ "The Decision on Reform of the Economic Structure" covers ten 
chapters totalling 16.000 Chinese characters and must be regarded as one of the most important documents pertaining to the Chinese reform process.

The Decision mentions that China now has over one million urban industrial and commercial enterprises with a work force totalling more than 80 million. The taxes and profits delivered by these enterprises account for over $80 \%$ of the state's revenue. Thus, the urban enterprises have a vital bearing on the national economy as well as on the state's financial and economic situation.

The Decision calls for a reform of every aspect of the entire economic structure. This involves a whole range of reforms, including planning, pricing, economic management, and the labor and wage system. These reforms should largely be accomplished within five years. The goal is to make the individual enterprise an independent economic entity responsible for its own profits and losses and able to act as a legal person with certain rigths and duties.

The Decision claims that in the reform of the planning system "it is necessary, first of all, to discard the traditional idea of pitting the planned economy against the commodity economy. ${ }^{\prime 26}$ In fact, according to the Decision, a socialist economy is a "planned commodity economy" and the difference between socialist and capitalist economy does not lie in whether commodity economy and the law of value are still functioning, but in the difference in ownership. In short, it is public ownership of the major means of production which defines a socialist system, not the structure of the planning system. The implication is that it is possible to attempt far-reaching reforms of the planning system without altering the fact that China is a socialist country.

The Chinese price system is based on administrative prices set by the state. Prices of labor, energy, and many raw materials have been separated from relative scarcities, which has resulted in an irrational price system that does not provide suitable information and signals to the economic actors. The Decision lists several examples of the irrational price system: inadequate price differentials for a given product with varying quality, irrational price ratios between different commodities, particularly the low prices for some mineral products and raw and semi-finished materials; and the retail price of major farm and side-line products being lower than their state purchasing price. The Decision admits that this situation constitutes an obstacle to the reform of the planning system: "Therefore, reform of the price system is the key to the reform of the entire economic structure. ${ }^{\prime 27}$

The Decision recommends a three-tiered pricing system which will reflect and also support the tripartite management system: planned prices for essential products covered by the state plan, floating or negotiated prices for pro- 
ducts under guidance planning, and free prices for products circulated in the free market.

Suggestions to pay more attention to what the Chinese call economic levers (pricing, taxation, credit, etc.) are combined with suggestions to implement a wage and labor reform "in accordance with the principle of linking wages with responsibilities and achievements" so as to reflect more fully "the differences between mental and manual, complex and simple, skilled and unskilled, and heavy and light work" ${ }^{28}$ Along these lines we also find a call for an enterprise management system where the director or manager assumes full responsibility.

The Decision points out that a thorough reform of the economic structure badly needs a contingent of managerial and administrative personnel, and especially managers who are knowledgeable in modern economics and technology. It is therefore necessary to promote a new generation of managerial personnel. This is called "reshuffling of leadership in enterprises", and was to be completed before the end of 1985 .

The Decision on reform of the economic structure was given wide coverage in the media in China as well as abroad. The Chinese used phrases like "great practical importance" and "far-reaching historical significance" in order to emphasize that this time the reform process did not aim at partial and minor alterations of the system, but rather had entered a stage of "comprehensive reform".

To be sure, following the Decision on reform of the economic structure, important changes took place in the realm of planning. In industrial production, the number of products controlled by the mandatory planning of the State Planning Commission were reduced from 123 to 60 , and the number of materials allocated through unified state distribution by the State Planning Commission and the State Bureau of Material Supply went down from 256 to $65 .{ }^{29}$ The types of agricultural and sideline products covered by mandatory plans declined from 29 to 10,30 and in late March the Central Committee issued a zhongfa that consolidated the shift from state planning to market regulation in farm production. State purchasing quotas were to be abolished, and instead the state would buy grain and cotton according to contracts and allow farmers to sell their surplus production on the open market. ${ }^{31}$ Other agricultural goods would be allowed to float at free market prices. ${ }^{32}$

1985 also saw further experimentation with a wage and labor reform, and industrial enterprises were given permission to keep their depreciation funds. Finally, an important reform of the Science and Technology management sys- 
tem was announced in March 1985, when the Central Committee issued its "Decision on Reform of the Science and Technology Management System". ${ }^{33}$ The Science and Technology reforms were aimed at science and technology development and technology transfer not only in accordance with the production needs, but also in line with the emerging combination of mandatory and guidance planning with the free market.

\section{Moratorium on Reform}

The introduction of these reform measures had a stimulating effect on economic performance, and during the first nine months of 1985 Chinese economic growth surged upward.

However, soon the old problems of inflation, budget deficits, excessive capital construction, etc., reappeared. Confronted with these signs of imbalance and with a marked drop in foreign exchange reserves due to large-scale import of consumer goods from Japan, the reformers were pressed to call a temporary halt to the implementation of further reforms. Recentralization and consolidation reappeared as the key words.

On April 12, 1986, the National People's Congress formally adopted China's Seventh Five-Year Plan, which will cover the $1986-1990$ period. ${ }^{34}$ The Plan introduces a two-year reform moratorium for the years 1986 and 1987. During this period efforts will be made to keep investments in control. Thus, investments will not exceed the 1985 level of 157 billion Yun for at least two years and the average accumulation rate will be maintained at 30 percent. Efforts will also be made to enhance macroeconomic control of the economy in order to achieve a "basic balance" and avoid a discrepancy between supply and demand.

Anticipated growth rates are modest, at least compared to the economic growth rates of the 1981-1985 period. Industrial output is targeted to increase 7.5 percent a year in the next five years, compared with an increase in industrial output in 1985 of 18 percent and an average growth of 12 percent over the past five years. Agriculture is planned to increase 4 percent a year in the plan period, which is significantly lower than the average annual growth of 8.1 percent between 1981 and 1985. Combined agricultural and industrial output is expected to grow 6.7 percent a year in the next five years, compared with the 11 percent.annual growth in the past five years. ${ }^{35}$ Clearly, the plan aims to slow down the overheated Chinese economy. 
The Chinese polity seems to generate the same policies and policy positions repeatedly. In the economic realm a pattern recurs of reform and readjustment, of decentralization and centralization, etc. Since 1978 we have seen two, possibly three, of these cycles.

Clearly there are deeply rooted systemic obstacles to reform. These are not just of an economic nature. In fact, the absence of basic political reform could be a major factor blocking full-fledged economic reforms.

\section{Political Reform}

In August 1980 an enlarged meeting of the Politburo was called to discuss the question of how to reform the leadership systems of the Party and the State. At the meeting Deng Xiaoping delivered an important speech addressing these issues. Deng's speech was not published at the time, but the Chinese press was full of allusions to it. ${ }^{36}$ The debate that unfolded and the policy proposals that were formulated came to be known as the gengshen reforms. ${ }^{37}$ The most elaborate of these reform proposals was the one put forward by Liao Gailong, a member of the policy study office under the Central Committee, at a seminar on party history held by the national party school system in $1980 .{ }^{38}$

In his August 1980 speech, Deng identified five major obstacles to political reform and democratization: bureaucracy, overconcentration of power, patriarchal methods, lifelong tenure of leading posts, and various kinds of privileges. In order to combat these phenomena and introduce reforms in the political sphere it was necessary to "fully practice people's democracy; ensure that all people truly enjoy the right to manage, through various effective forms, state affairs and particularly local state power at the grass-roots level and the various enterprises and institutions. ${ }^{\prime \prime 9}$ Deng also mentioned three objectives in the socialist modernization process: (1) to catch up with the developed capitalist countries in terms of economic performance; (2) to create a democracy "which is at a higher level than that of capitalist countries", and (3) to educate more qualified people than the developed countries..$^{40}$

Deng is very much aware that the above-mentioned problems constitute obstacles to the successful implementation of economic reforms. He argues, for example, that the overconcentration of power means the concentration of all power in the Party committees. This constitutes a major problem because the power of the Party committees themselves is often in the hands of party 
secretaries, especially the first secretaries. In this way "centralized Party leadership" often turns into leadership by individuals.

On this issue, Liao Gailong goes even further and, allegedly basing himself on remarks made by Deng in August 1980, in fact proposes the abolition of the concept of the leadership by the party committes at the basic levels:

Why must we carry out such reforms? Because the kind of system of leadership practiced in the past in enterprises and businesses, is - though called the leadership of the party committees - actually a system of individual dictatorial and arbitrary rule by the party committee secretaries, who have the final say on any matter. Moreover, these party committee secretaries are mostly nonprofessionals in the enterprises and businesses over which they exercise leadership. ${ }^{41}$

Although Deng would phrase his objection to too much Party interference in enterprise management differently, it is probably correct to assume that Liao Gailong is in agreement with Deng Xiaoping on this issue. A speech for restricted circulation, delivered by Deng in the fall of 1980 and only recently made available, substantiates this proposition. ${ }^{42}$ In this speech, Deng stated that is is ncessary to reduce the power of the Party at the basic level. Said Deng:

At the grass-roots level, we must make up our mind to change the situation in which party members dominate the masses, party branch secretaries dominate all other cadres, and party organizations dominate all other organizations. Our party committees should no longer take on and intervene in everything. ${ }^{43}$

In wanting to abrogate the privileges enjoyed by basic-level party committees and their secretaries, Deng is in complete agreement with Liao Gailong. He thought that if the Party did not introduce reforms to solve the problems, it would be placed in a position "antagonistic to the masses". He warned that when the Polish Communist Party had failed to redefine its position in society, the Polish workers had reacted by establishing their own independent trade unions, and he asked: "Can we say we are not facing a similar problem?" " $_{44}$

Liao Gailong is also in favor of a loosening of Party control over Chinese society, and an increase in the autonomy of other organizations. He proposes to divide the National People's Congress into two houses where one house should be chosen on the basis of territory and the other on the basis of a social 
or functional representation. These two houses would jointly execute legislative power, jointly supervise the work of the government, and jointly exercise the highest state power. They would impose a constraint on each other so that neither house would have the final say..$^{45}$ There should also be an independent judiciary which would mean that when a court passed a verdict, it would not have to send it to any party committee for examination. ${ }^{46}$ The workers should be permitted to elect the officials of the trade unions, making these unions represent the interests of the masses rather than the Party. If this did not happen the working class might rise in rebellion as had happened in Poland. ${ }^{47}$ The work of the Party should be separated from the work of administrative organs, in enterprises and businesses, and enterprise management should be democratized. ${ }^{48}$ The next Part congress should elect three parallel central committees which will "mutually supervise and impose constraints on each other", ${ }^{\prime 9}$ as Deng, according to Liao Gailong, had suggested in August 1980.

In sum, Liao Gailong proposed the introduction of changes or reforms that would change the political system into a system characterized by "checks and balances" between various political institutions and organs rather than by the all-pervasive dominance of a strong centralized Party. What is at stake is no less than an attempt to introduce pluralistic elements into the Chinese political system. Again Liao Gailong seemed to have the support of Deng Xiaoping. To be sure, in his August 1980 Politburo speech Deng had claimed that "the purpose of reforming the system of Party and state leadership is precisely to adhere to and strengthen, rather than weaken, Party leadership and discipline. " But in the other, shorter, speech for restricted circulation from the same period, he said "that the method of the Party ruling over the country cannot be practiced any more", and that it was necessary to separate the Party organization from the government and other organs of state power. ${ }^{51}$ By suggesting changes along these lines Liao Gailong and Deng Xiaoping approached the threshold of systemic reform and not just improvements of the existing system.

In 1981 the reform debate receded, faced with the realities of economic retrenchment and consolidation. In fact, only a few of the gengshen reforms were implemented during the following five years. The term reform became almost synonomous with economic reform. 


\section{The Present Reform Debate}

In the summer of 1986 , the notion of political reform staged a comeback. A spate of articles on the theme of reform of the political system (zhengzhi tizhi gaige) appeared in Chinese media in July-August-September, and since May several conferences have been convened to address this issue. The present debate has, like the gengshen reform debate, been initiated by Deng Xiaoping. This happened at a meeting with the provincial governors in April, where Deng gave a talk that called for a reform of the political system. ${ }^{52}$

In June Deng again on several occasions addressed this topic, and at a meeting in the Politburo's Standing Committee he emphasized that ultimately reform of the political system and reform of the economic system support and supplement each other, and he argued that political reforms were the indispensable concomitant of economic reform. ${ }^{.3}$ On July 1 , the People's Daily editorial advocated reform of that part of the political system that was no longer in accordance with the economic base. On July, 16, Wang Zhaoguo, member of the Party Secretariat elaborated on the need for reforms in a speech at the CCP Central Party School; and on July 31, another political heavyweight, vice-premier Wan $\mathrm{Li}$, joined the choir. ${ }^{54} \mathrm{It}$ is also noteworthy that Deng Xiaoping's speech from August 1980, which started the gengshen reform debate, reappeared in excerpts in Beijing Review in August 1986. ${ }^{55}$

The debate in the summer of 1986 explicitly connected political reform with economic reform. ${ }^{56}$ In particular two reform proposals had a direct bearing on the economy as well as on the political arena. One was the reduction of the power of local governments and local party committees. ${ }^{57}$ This had actually been implemented on a trial basis in a number of small and medium-sized cities. The other was the introduction of a new responsibility system for enterprise directors and managers that would strengthen the work of the enterprise management and reduce the powers of the enterprise Party committee. This reform was already suggested in speeches by Deng Xiaoping and Liao Gailong in 1980.

On September 15, the Central Committee and the State Council issued the "Regulations on the work of the directors of industrial enterprises owned by the whole people", the "Regulations on the work of grass-roots party organizations in industrial enterprises owned by the whole people", and the "Regulations on the congresses of staff and workers of industrial enterprises owned by the whole people." The Central Committee and the State Council also issued a joint circular calling on state enterprises to implement these regulations from October $1 .{ }^{58}$ 
The reform process had picked up momentum again, and it was expected that the upcoming 6th Plenary Session of the present Central Committee would decide on a major reform of the political system. The Plenary Session which took place in late September adopted an important resolution. ${ }^{59}$ It stated that "reforms mean the development and perfection of the socialist system", that it is not possible to achieve modernization without democracy, that democracy must be institutionalized and legally codified, and that "the Party must conduct its activities within the limits permitted by the Constitution and the laws of the state." ${ }^{60}$ The Resolution admits that reform of the political system will be "a very complicated task". After thorough investigation and study the Central Committee will work out plans to accomplish political reform so that it may "proceed step by step and with proper guidance". ${ }^{61}$

"Proper guidance" seems to be a key phrase. It denotes that the Central Committe will not abolish "the leading role of the Party" in the reform process. On the contrary, "the leading role of the Party" and "the people's democratic dictatorship" are principles that will be upheld. The resolution does not give the green light for any systemic reform. Major decisions on this issue were postponed to the 13th Party Congress, scheduled to convene in October 1988. The conservative wing of the Party had once again weathered the storm.

\section{Systemic Change?}

Seweryn Bialer has proposed a typology of reforms to be used when discussing the possible departure from the Stalinist model. ${ }^{62}$ The first type he calls policy reforms. These aim to achieve different policy outcomes by changing policy inputs. Here the decision-making process is viewed as a "black box" and is not changed. In Bialer's view the main instruments of policy reforms are pricing, taxation, and subsidies, and they address the issue of resource allocation.

The second type is, according to Bialer, organizational-administrative reforms. Here the aim is to change the process of decision-making, i.e. to interfere with how the "black box" works. The main instruments of this type of reform are the allocation and distribution of responsibilities, obligations, authority relations, the size and composition of existing organizations, etc.

The third type Bialer calls structural reforms. These aim to change the very parameters within which the decision-making process and the political-economic patterns of behaviour operate and are confined. The main instruments 
have to do with the process of institutionalization and concern the creation, abolition, or fundamental change of politico-economic institutions.

The differentiation of these three types of reforms proposed by Bialer follows the distinction between changes in the system and changes of the system. Thus policy reforms and organizational-administrative reforms belong to the category of changes in the system, whereas structural-institutional reforms must be classified under reforms of the system.

In the Chinese case one could accordingly argue that the reforms introduced thus far all belong to the two first categories (policy reforms and organizational-administrative reforms). The reforms have sought to improve particular aspects of the system, but they have not gone beyond the borderline to radical reform (structural reform) which tries to change the system itself.

In the political field such a threshold would be crossed if, for example, the decision-making process were changed. This could happen if a more pluralistic political system was established in the sense that the Party was no longer the source of ultimate power. What is involved is the introduction of checks and balances in the political system. However, in China as well as in other centralized planning economies the leading role of the Party seems to be the sine qua non of socialism. Here the limits of possible reform initiatives seem to have been reached.

\section{Postscript}

The decison of the Politburo of the CCP on January 16 to "unanimously" accept General Secretary Hu Yaobang's resignation and to replace him with Premier Zhao Ziyang came as a surprise and created an atmosphere of confusion and uncertainty.${ }^{63}$ Western analysts tended to believe that it was an outcome of the battle between reformers and conservatives within the Party leadership. ${ }^{64}$ According to this line of thought, the conservatives had used the political instability caused by the student demonstrations to inflict on the reformers their most serious defeat since they took the offensive in 1978. However, the new Acting General Secretary Zhao Ziyang had been one of the the chief architects of China's reform process all along, and it would seem that it is too simplified to view Hu Yaobang's dismissal as the result of a clear-cut two-line struggle between the reformers and the conservatives.

In this postscript an attempt will be made to evaluate the significance of the recent leadership changes. Do they signal an orthodox backlash and are the 
reforms really in jeopardy? The main part of the postscript, however, will be devoted to an analysis of what happened when it was decided to oust $\mathrm{Hu}$ Yaobang. In other words: what was the background and what were the reasons? Hopefully, this will throw some light on the question of the significance of the incident for the reform project as such.

Usually leadership changes in China are shrouded in mystery due to the lack of information available to the outside observer. This time one is in a much better position since the major factors influencing the decision to dismiss $\mathrm{Hu}$ Yaobang are described in a series of Central Documents (zhongfa). The collection is entitled Feidang zhongyang youguan 'fan ziyouhua' douzheng zhongfa wenjian huibian (Collection of Central Documents on the struggle against liberalism issued by the CCP Central Committee). ${ }^{65}$

Zhongfa no. 1 of 1987 was issued on January 6. It contains the main points of Deng Xiaoping's remarks on the problem of student disturbances, at a meeting on December 30, 1986, where Wan Li, Hu Qili, Li Peng, He Dongchang, Hu Yaobang and Zhao Ziyang also were present. Deng said that the student demonstrations were the result of failing to take a clear stand against bourgeois liberalism (zichan jieji ziyouhua). Over a period of several years bourgeois liberalism had been allowed to spread unchecked and the four cardinal principles had not been upheld. ${ }^{60}$

Deng said that he "had read Fang Lizhi's speeches, which didn't at all sound like they were said by a Party member", and he continued: "Why do we have such a person in the Party? It is not a question of persuading him to withdraw; he should be thrown out!"67 He also had some harsh comments on Wang Ruowang who he regarded as very reckless (changkuang de hen). He wondered why he had not been expelled from the Party even though he himself had ordered it long ago. ${ }^{68}$

Deng warned the other participants in the meeting that developing democracy in China did not imply introducing bourgeois democracy (zichan jieji minzhu). China should not establish a bourgeois democratic system like the American with the division of power between three branches of government: "I always criticize the Americans and say they have three governments." 69

In a statement that seems to contravene what has been widely believed in the West, Deng implied that China did not take its relations with the West into special consideration in matters dealing with pólitical dissent and demands for democratization. He speficied his remarks by pointing to Wei Jingsheng who in 1979 was sentenced to 15 years of prison: "Do you mean to say that China's reputation suffered as a result? We arrested him and we haven't let him go and 
China's image has not suffered the slightest damage. Our reputation is getting better day by day." 70

Discussing events in Poland, Deng said that at the time of the Polish crisis the Polish leaders had been clear-headed and resolute. They were faced with a united opposition from the trade unions and the church and they resorted to military measures to bring the situation under control: "This proves that it won't do without the methods of dictatorship", only one should use these methods carefully and arrest as few people as possible and in as bloodless a manner as possible. ${ }^{11}$

Conluding, Deng said that the opposition against bourgeois liberalism would last for at least 20 years. If China tried to import Western style democracy, it would only end in chaos. ${ }^{72}$ Socialist construction in China should be carried out under conditions of stability and solidarity and implemented with leadership and in good order, so although China should not worry about what foreigners said, it was, according to Deng, important to show to the outside world that the political situation was stable.

Summing up: Deng indirectly blamed Hu Yaobang for failing to take a clear stand against bourgeois liberalism. He had been guilty of a laissez-faire attitude and had allowed things to take their own course. He should, for example, have expelled Fang Lizhi, Wang Ruowang and Liu Binyan. Since "the people who have behaved badly all are members of our own Communist Party" ${ }^{\prime 7}$ the responsibility rested with $\mathrm{Hu}$ in his position as General Secretary.

\section{Bourgeois Liberalism}

Zhongfa no. 2 is dated January 9, 1987. It contains a speech by Deng Xiaoping at the 6th Plenary Session of the 12th Central Committee on September 28, 1986. In this speech Deng very sharply criticizes bourgois liberalism. In defining liberalism Deng claims that "liberalism itself is bourgeois in nature; there is no such thing as proletarian or socialist liberalism." ${ }^{\prime 74}$

Returning to the notion that the idelogical tendency (sichao) of bourgeois liberalism had existed for several years, Deng referred to the resolution adopted by the National People's Congress in 1980 to delete the "four bigs" (the rights of the citizens to "speak out freely, air their views fully, hold great debates, and put up big-character posters") from the constitution. Asked Deng:

Why did we do this? Because there was an ideological tendency of liberalism. If we had gone in for liberalism, it would have undermined our political stability and unity, without which construction would be out of the question. ${ }^{75}$ 
Abolishing the "four bigs" by the Chinese authorities was part of an attempt to suppress the unofficial democracy movement which still showed some activity in 1980, although some of the movement's leaders, including Wei Jingsheng, had been arrested in $1979 .{ }^{76}$ Now Deng claimed that the reason for the crack-down on the movement was that they were leading China "down the road to capitalism" ${ }^{\prime 7}$

Commenting on the time horizon for the "struggle against bourgeois liberalism", Deng remarked that it will "have to be carried on for the next 10 or 20 years ${ }^{\prime \prime} .{ }^{78} \mathrm{He}$ warned that if this ideological tendency is not checked, it will merge with undesirable "foreign things" that will inevitably find their way into China because of the open door policy and will deal a blow against the modernization program.

Summing up: in publishing this speech in January, the Chinese leadership probably wanted to show that Deng already in September 1986 had warned against the danger of bourgeois liberalism. If allowed to spread it would endanger the open door policy and the economic modernization program.

\section{Hu Yaobang's Six Mistakes}

Zhongfa no. 3 was issued on January 17. It consists of a report by Bo Yibo which was delivered at the enlarged Politburo meeting the day before, when it was decided to oust $\mathrm{Hu}$ Yaobang. The report is in the form of a criticism of the General Secretary's mistakes. According to Bo Yibo they were six.

(1) There were people who had taken advantage of the opportunity presented by the reform of the political system to advocate liberalism, full-scale westernization (quanpan xifanghua) and the introduction of the capitalist economic and political system. This had formed the background for the student unrest that spread throughout the country in late 1986. Hu Yaobang's mistake was that he had "shown weakness" and had not intervened to stop this development.

(2) Hu had failed to support the Party rectification which was spelled out at the Second Plenary Session of the 12th Central Committee, and in ideological matters he had only criticized the left and never the right. This amounts to a criticism for being a rightist.

(3) Hu's economic policies had caused an overheated economy. His emphasis on "consumption comes first" was something he had taken from Western economics, and it was not "compatible with the concept of the relations between production and consumption in Marxist political economics". ${ }^{79}$

(4) In political work $\mathrm{Hu}$ failed to follow the line laid down at the Third Plenary 
Session of the 11th Central Committee in December 1978 and he ignored the Constitution and the Party Program.

(5) In foreign affairs "he said too many things he ought not to have said" and violated existing regulations on how to run foreign relations work..$^{80}$

(6) He often expressed his opinions on important problems without consulting the Central Committee. All these faults were aggravated by Hu's failure to listen to leading comrades from the Politburo, especially Deng Xiaoping.

After Bo Yibo had delivered his criticism, Hu Yaobang admitted that he had committed "grave mistakes", and failed to perform the duties entrusted to him by the Party. He would "certainly" do what the Party expected of him and make a frank and sincere self-examination. ${ }^{81}$

\section{Limits to the Campaign}

Zhongfa no. 4 was sent out internally in the Party on January 28. Its main purpose was to set some limits on the campaign against bourgeois liberalism. The campaign was to be restricted to the Party and the idelogical arena and was not to be allowed to turn into a mass movement. Such methods as pointing out names in newspapers and periodicals and using public criticism was only to be used "in very special cases" such as those of Party members who have great influence, who have publicly been promoting bourgeois liberalism, and who have repeatedly been re-educated as to their mistakes and refuse to reform. Even with regard to these people appropriate work should be found "in which they can make use of their special skills, and full respect must be shown for their rights as citizens. "In rectifying the "errors of political ideology" it was by no means permitted to interfere with the reforms or the policy of opening up to the outside world..$^{83}$

Zhongfa no. 4 announced some tough measures in relation to publishing. In the future, departments concerned with public opinion should set up necessary systems of inspection and supervision. Some people would also be removed from their posts, especially those who had demanded bourgeois liberalism. ${ }^{84}$ But the red thread in this zhongfa was clearly to set limits on the extent of the campaign.

Zhongfa no. 5 was released on February 4 . It is not contained in the present collection of zhongfa. But from other sources it is clear that it supplements zhongfa no. 4 in setting limits to the campaing against bourgeois liberalism. ${ }^{85}$ Hence, it specified that the campaign was not to be extended to the countryside. 
Zhongfa no. 6 is dated February 6. It stresses the necessity to propagate the decision of the National People's Congress on the strengthening of legal work and defending stability and unity. The document also emphasizes the four fundamental principles and especially the leading role of the Party, and it is stated that these principles should be followed by all China, and not only Party members. ${ }^{86}$

\section{Concluding Remarks}

These zhongfa, and especially the first two, indicate that the growing influence of Western ideology, or bourgeois liberalism, was a major factor in the fall of $\mathrm{Hu}$ Yaobang. Closely connected with this notion is the perceived danger of westernization. ${ }^{87}$ Although the concept of westernization (xifanghua) refers to attempts to introduce the "capitalist ideology and social system" of the west, it does not imply that the open door policy should be terminated. It is also clearly stated that the reform process should be continued.

In practice, however, the conservative faction in the party leadership was profitting from the incident. Peng Zhen has considerably strengthened his position by successfully attempting to bring the National People's Congress more into the political process. ${ }^{88}$ Deng Liqun has been able to demonstrate that although he may not be the actual head of the CCP Propganda Department any more, he still exercises a tremendous influence in the ideological realm. Chen Yun is known for his preference for a balanced and orderly development of the economy, and he has continuously warned against proceeding too rapidly with the reform process. Perhaps even more importantly, the older party leaders who were believed to have accepted a situation of semi-retirement have been quite active in coordinating the attacks against Hu Yaobang. It is noteworthy that it was Bo Yibo, the 79-year old vice-chairman of the Central Advisory Commission, who at the Politburo meeting in January actually formulated the criticism of $\mathrm{Hu}$. This lends substance to the assumption that Hu's attempt to retire the Party elders in connection with preparations for the 13th Party Congress in October backfired. There were also signs that Hu never succeeded in achieving the support of the army, and therefore was deprived of an important factor in the Chinese power equation.

It is probably not correct to assume that the changes in leadership and the expulsion of some Party members such as Fang Lizhi, Wang Ruowang, and Liu Binyan signified a reversal of the reform process. It was probably more a question of how fast to go rather than where to go. In addition, Hu Yaobang's style of leadership perhaps raised doubts in some of the Party elders, including 
Deng himself, as to his abilities as leader of the Party. It seems that Deng and Zhao Ziyang have been able to limit the damage to the reform project caused by Hu's fall. There is still a good chance that a resolution on reform of the political system may be adopted at the 13 th Congress this October.

\section{NOTES}

1 See Martin Lockett and Craig R. Littler, "Trends in Enterprise Management, 1979-1982", World Development, Vol. 11, No. 8 (1983), pp. 683-704.

2 Wang Bingqian, "Report on Financial Work" (Delivered at the Third Session of the Fifth National People's Congress on August 30, 1980), Beijing Review, 1980, No. 39, pp. 11-22.

3 Extrabudgetary funds are funds which are not included in the state budget, but are retained, administered and used by local authorities, units and enterprises. See "Explanation of Terms Used in the Sixth Five-Year Plan", Foreign Broadcast Information Service (hereafter FBIS), China: Economic Report (April 29, 1983), pp. 50-91. Jin Xin reports that extrabudgetary income has increased 66-fold since 1953, and constituted about 60 billion Yuan in 1981. See Jin Xin, "Strengthen Management of Extrabudgetary Funds - Improve the Efectiveness of Funds Utilization", FBIS, China: Economic Report (June 8, 1983), pp. 43-50.

4 See Teyue pinglunyuan (Special Commentator), "Tiaozheng shiqi jiben jianshe bixu gaodu jizhong tongyi" (Capital construction must be centralized and unified to a high degree in the period of readjustment), Renmin Ribao, December 30, 1980.

5 See Kjeld Erik Brødsgaard, "Paradigmatic Change, Readjustment and Reform in the Chinese Economy, 1953-1981, Part II", Modem China, Vol. 9, No. 2 (April 1983), pp. 253-272.

6 For a more detailed discussion of this system, see, for example, Jiang Yiwei, "Qiye de quanmian zhengdun shi jianshexing de zhengdun" (Overall enterprise reorganization is constructive reorganization), Jingji Guanli, 1982, No. 4, pp. 14-19. How the system worked at the national model, the Capital Iron and Steel Company, is described in Shou gang shixing jingji zerenzhi de jingyan (Beijing: Beijing Ribao Chubanshe, 1982).

7 Xue Muqiao, "Jihua jingji wei zhu, shichang tiaojie wei fu" (Take planned economy as the dominant factor and market regulation as a supplement), Hongqi, 1983, No.8, pp. 30-33.

8 Gong Shiqi and $X u Y i$, "Jianchi jihua jingii wei zhu shichang tiaojie wei fu" (Adhere to planned economy as the dominant factor and the market as the supplement), Jingii Yanjiu, 1982, No. 6, pp. 38. See also Xiang Qiyuan, Zhang Zhuoyuan, and Tian Jinghai, "Jianchi jihua jingji shi tigao jingji xiaoguo de genben baozheng" (Adherence to planned economy is the basic guarantee for raising economic results), Jingji Yanjiu, 1982, No. 7, pp. 14-20.

9 Xue Muqiao, op.cit.; See also Su Xing, "Zhongguo de jihua jingji yu shichang" (China's planned economy and the mar- 
ket), Jingii Yanjiu, 1982, No. 8, pp. 1419.

10 Hu Yaobang, "Create a New Situation in All Fields of Socialist Modernization" (Report to the 12th National Congress of the Communist Party of China, September 1, 1982), Beijing Review 1982, No. 37, pp. 1-40.

11 Ibid., p. 19.

12 Liu Guoguang, "Jianchi jingji tizhi gaige de jiben fangxiang" (Adhere to the basic direction for reform of the economic system), Renmin Ribao, September 6, 1982.

13 Ibid.

14 Ibid.

15 Ibid.

16 "Jianli gengiia fuhe woguo qingkuang de jihua guanli tizhi" (Establish a planning system better suited to our country's conditions), Renmin Ribao, September 21, 1982.

17 lbid.

$18 \mathrm{Ibid}$.

19 I wish to thank Professor Zhang Youren, Department of Economics, Beijing University, for arranging a series of interviews at the Chinese Academy of Social Sciences in November-December 1982 with Liu Guoguang, Dong Fureng, and Yang Jianbai. Thanks are also due to the Scandinavian Institute of Asian Studies for financially supporting my trip to China in 1982-1983.

20 Yao Yilin, "Report on the 1983 Plan for National Economic and Social Development" (Delivered at the First Session of the Sixth National People's Congress on June 7, 1983), Beijing Review, 1983, No, 28, pp. I-VIII; Survey of World Broadcasts (hereafter SWB), FE/W1244/A/7 (July 13, 1983); SWB, FE/W1249/C1/4 (August 17, 1983).

21 SWB, FE/W1251/A/4 (August 31, 1983).

22 See Frederick W. Crook, "The Reform of the Commune System and the Rise of the Township-Collective-Household System", in China's Economy Looks To- ward the Year 2000, Vol. 1, The Four Modernizations (Washington, D.C.: Government Printing Office, 1986), pp. 354-375.

23 FBIS, Joint Publications Research Service, China: Economic Affairs (hereafter FBIS, JPRS-CEA)-84-105 (December 21, 1984), pp. 7-11.

24 Xue Muqiao, "Keep Abreast of the New Situation, Improve the Planned System", Jingji Ribao, August 16, 1984. An English translation appeares in FBIS, JPRS-CEA-84-085, pp. 2-6.

25 See "Decision of the Central Committee of the Communist Party of China on Reform of the Economic Structure" (Adopted by the 12th Central Committee of the Comunist Party of China at its Third Session on October 20, 1984), Beijing Review, 1984, No. 44, pp. I-XVI. For an illuminating overview of the Chinese reform process, 1978-1984, see Harry Harding, "Reform in China: A Mid-Course Assessment", Journal of Northeast Asian Studies, Vol. 3, No. 2 (1984), pp. 3-25.

26 "Decision of the Central Committee of the Communist Party of China on Reform of the Economic Structure", op. cit. This phrase was the object of a large number of articles in the fall and winter of 1984. See, for example, Guangming Ribao on December 9 and December 10, 1984 and Jingji Ribao on November 19 and 21, 1984. See also the article by Liu Guoguang who by now had become vice-president of the Chinese Academy of Social Sciences: "Gaizao jingji tizhi moshi, wanshan shehui zhuyi zhidu xuexi 'zhonggong zhongyang guanyu jingji tizhi gaige de jueding' - yixie tihui" (Transform the model of the economic structure, perfect the socialist system some lessons to be derived from the CCP Central Committee Decision on Reform of the Economic Structure), Jingji Yanjiu, 1984, No. 12, pp. 16-24.

27 "Decision of the Central Committee of 
the Communist Party of China on Reform of the Economic Structure", op.cit.

\section{Ibid.}

29 See Song Ping, "Guanyu 1985 nian guomin jingji he shehui fazhan jihua caoan de baogao" (Report on the 1985 National Economic and Social Development Plan), Renmin Ribao, April 13, 1985.

30 FBIS, JPRS-CEA-84-105 (December 21, 1984), pp. 31-32.

31 "Zhonggong zhongyang, guowuyuan guanyu jinyibu huoyue nongcun jingji de shixiang zhengce", Zhongguo Nongye Nianjian 1985, pp. 1-3. See also Zhao Ziyang, "Fangkai nongchanpin jiage, cujin nongcun chanye jiegou de tiaozheng" (Set free the prices of agricultural products, advance readjustment of the rural property structure), Hongqi, 1985, No. 3, pp. 10-14.

32 For further details, see Thiagarajan Manoharan, "The 1981 Economic Contract Law of the People's Republic of China: A Brief Economic Analysis of Legal Provisions", Review of Socialist Law, No. 12 (1986), pp. 101-138.

33 "Zhonggong zhongyang guanyu kexue jishu tizhi gaige de jueding" (Central Decision on reform of the science and technology system), Guowuyuan Gongbao, No. 461 (April 10, 1985), pp. 201-208.

34 See Beijing Review, 1986, No. 17, pp. IXXIII.

35 See Kjeld Erik Brødsgaard, "Breaking Away From the Soviet Model: Issues and Problems in the Chinese Quest for Socialist Development" (forthcoming).

36 Deng Xiaoping, "Dang he guojia lingdao zhidu de gaige" (Reform of the leadership systems of the party and state). This text appears in Sanzhong quanhui yilai zhongyao wengao xuanbian (Beijing: Renmin Chubanshe, 1982), pp. 510-535. This two-volume collection of speeches was published internally by the Central Committee in September 1982. There is an excerpt of the speech in Shiyi jie sanzhong quanhui yilai jingji zhengce wen- xian xuanbian (Beijing: Renmin Chubanshe, 1982), pp. 64-75. A version available to the Chinese public appeared for the first time in the summer of 1983 in Deng Xiaoping wenxuan, 1975-1982 (Renmin Chubanshe, 1982), pp. 280302.

37 Most of the year 1980 was called gengshen according to the traditional 60-year calendar cycle.

38 This text, "Lishi de jingyan he women de fazhan daolu" (Historical experience and our development path), was not openly published in China either. A translation of the speech based on a manuscript transcribed from a tape recording appears in Issues \& Studies, October, November and December, 1981. Parts of the speech have been published in Qishi Niandai, No. 134 (March 1981), pp. 38-48 and translated into English in FBIS, Daily Report: China (hereafter FBIS-CHI), March 16, 1981, pp. U1U19. A photolithographic reproduction of the Chinese text, which will be referred to in the following, appears in Zhonggong Yanjiu, Vol. 15, No. 9 (September 15, 1981), pp. 108-177. For an analysis, see also Stuart Schram, "'Economics in Command?" Ideology and Policy Since the Third Plenum, 1978-1984', The China Quarterly, No. 99 (1984), pp. 417-461, and Harry Harding, "Political Development in Post-Mao China", in A. Doak Barnett and Ralph N. Clough (eds.), Modernizing China (Boulder, Westview Press, 1986), pp. 13-37.

39 Deng Xiaoping, "Dang he guojia lingdao zhidu de gaige", op.cit.

40 Ibid.

41 Liao Gailong, "Lishi de jingyan he women de fazhan daolu", op.cit., p. 169.

42 "A Speech of Deng Xiaoping for Restricted Use Only", FBIS-CHI-86-117 (June 18, 1986), W1-2.

43. Ibid.

44 Ibid.

45 Liao Gailong, op, cit., p. 164. 
46 Ibid., p. 165.

47 Ibid., p. 67.

48 Ibid., p. 170.

49 Ibid., p. $171 .$.

50 Deng Xiaoping, "Dang he guojia lingdao zhidu de gaige", op.cit.

51 Deng Xiaoping, "A Speech of Deng Xiaoping for Restricted Use Only", op.cit.

52 SWB, July 25, 1986.

53 See Peter Schier, "Der Diskussion ber politische Reformen und ihre Hintergründe", China aktuell, August 1986, pp. 534-538.

54 See Wang Zhaoguo, "Gaohao gaige shi zhongqingnian ganbu de diyiwei lishi zeren" (To do a good job in reform is the primary historical responsibility of young and middle-aged cadres), Hongqi, 1986, No. 19, pp. 6-15; and Wan Li, "Juece minzhuhua he keshu shi zhengzhi tizhi gaige de yige zhongyao keti" (Democratic and scientific decision-making is an important aspect of reforming the political system), Renmin Ribao, August 15, 1986.

55 Beijing Review, 1986, No. 32 (August 11, 1986).

56 See, for example, Bao Xinjian, "Woguo zhengzhi tizhi gaige zongti mubiao tantao" (Investigation of the general goal of the reform of China's political system), Guangming Ribao, July 14, 1986. See also FBIS-CHI-86-141 (July 23, 1986); FBIS-CHI-86-153, (August 8, 1986).

57 FBIS-CHI-86-143 (July 25, 1986), W4-7.

58 See SWB, FE/8401/BIl/9-11 (October 28, 1986).

59 "Resolution of the Central Committee of the Communist Party of China on the Guiding Principles for Building a Socialist Society With an Advanced Culture and Ideology" (Adopted at the Sixth Plenary Session of the 12th Central Committee of the Communist Party of China on September 28, 1986), Beijing Review, 1986, No. 40 (October 6, 1986), pp. IVIII.
60 No account, however brief, of the economic and political reform process in post-Mao China can ignore the emphasis based on legality. Perhaps the most concrete manifestation of this emphasis in a socialist country like China is the promulgation of the 1986 General Provision of Civil Law, which incorporates the discussion in the PRC on a civil code. The general provisions reflected in various ways the general nature of law, the class character of law and the socialist character of law. It is still not unambiguously clear whether the party and the administration are subject to the legal, juridical processes before a court of law. For further details, see Thiagarajan Manoharan, "The 1981 Economic Contract Law and the 1986 General Provisions of Civil Law of the People's Republic of China - A Supplementary Note", Review of Socialist Law, No. 13, 1986 (forthcoming).

61 "Resolution of the Central Committee of the Communist Party of China on the Guiding Principles for Building a Socialist Society with an Advanced Culture and Ideology", op.cit.

62 Severyn Bialer, "Stalinism and anti-Stalinism and Soviet Reform", paper prepared for the conference on "To Reform the Chinese Political Order", June 18-23, 1984, Harwichport, Massachusetts.

63 See "Zhonggong zhongyang zhengzhiju kuoda huiyi gongbao" (Communique from the enlarged meeting of the Politbureau of Central Committee of the Communist Party of China), Renmin Ribao, January 17, 1987.

$64 \mathrm{See}$, for example, Robert Delfs, "Reforms in Jeopardy", Far Eastern Economic Review, January 26, 1987, p. 10; and Peter Schier, "Der Sturz des Hu Yaobang - Orthodoxe Marxisten und Alte Berater schlagen zurck", China aktuell, January 1987, pp. 63-68.

65 "Feidang zhongyang you guan 'fan ziyouhua' douzheng zhongfa wenjian 
huibian" (Collection of Central Documents on the struggle against liberalism issued by the CCP Central Committee). The collection is from Taiwan and it is undated. It is undoubtedly authentic.

66 The four fundamental principles are the socialist road, the people's democratic dictatorship, the leadership of the Party, and Marxism-Leninism-Mao Zedong Thought.

67 "Feidang zhongyang you guan 'fan ziyouhua' douzheng zhongfa wenjian huibian", op. cit., p. 3.

68 Ibid., p. 4.

69 Ibid.

70 Ibid.

71 Ibid., p. 5.

72 lbid., p. 6.

73 Ibid. p. 5.

74 Ibid., p. 11.

75 lbid., p. 11-12.

76 For a discussion of the democracy movement of 1978-1979, see Kjeld Erik Brødsgaard, "The Democracy Movement in China, 1978-1979: Opposition Movements, Wall Poster Campaigns, and Underground Journals", Asian Survey, Vol. XXI, No. 7 (July 1981), pp. 747-774.

77 "Feidang zhongyang you guan 'fan ziyouhua'. douzheng zhongfa wenjian huibian", op.cit., p. 12.

$78 \mathrm{lbid}$.

79 Ibid., p. 19.

80 Ibid.

81 lbid, , p. 20.

82 lbid., p. 27.
83 Ibid., p. 28.

84 Ibid., p. 32.

85 See, for example, Zhengming, 1987, No. 3, p. 6 .

86 "Feidang zhongyang you guan 'fan ziyouhua' douzheng zhongfa wenjian huibian", op.cit., p. 35.

87 On the relationship between bourgeois liberalism and westernization, see Benbao pinglunyuan (Renmin Ribao Commentator), "Quanpan xihua" jiu shi quanpan fouding shehuizhuyi" (Complete westernization is a complete denial of socialism), Renmin Ribao, January 12, 1987; and Chen Junsheng, "Zai gaige, kaifeng zhong jianchi sixiang jiben yuanze" (In reform and the open door policy adhere to the four fundamental principles), Renmin Ribao, January 12 , 1987.

88 The April 8 interview Peng gave to journalists from Hong Kong and Macao seems to indicate that Peng played an important role in ousting Hu Yaobang and in initiating the campaign against bourgeois liberalism. Although Peng denies harbouring any wishes of entering the Politburo Standing Committee, and has turned down several proposals to do so - "I shall be 85 in October, what can I do on the Standing Committee" - he probably feels that his status and prestige in the party would entitle him to a seat along with the other Party elders, Chen Yun, Deng Xiaoping, and Li Xiannian. See $S W B, F E / 8540 / C 2 / 1-17$. 